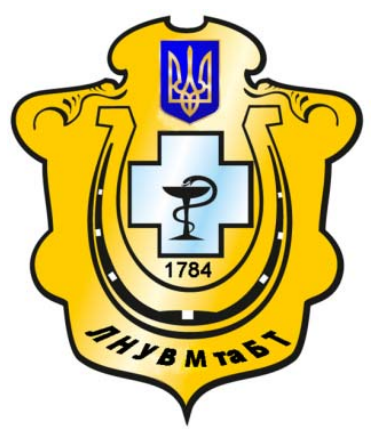

Науковий вісник Львівського національного університету ветеринарної медицини та біотехнологій імені С.3. Гжицького

Scientific Messenger of Lviv National University of Veterinary Medicine and Biotechnologies named after S.Z. Gzhytskyj

doi:10.15421/nvlvet7317

ISSN 2518-7554 print

ISSN 2518-1327 online

$\underline{\text { http://nvlvet.com.ua/ }}$

УДК 619:616.07:619:616.34:636.2

\title{
Етіологія та клініко-біохімічні показники крові за аліментарної остеодистрофії корів
}

\author{
Л.Г. Слівінська, С.К. Демидюк, А.Р. Щербатий, В.Л. Федорович, І.О. Тиндик \\ therapy@lvet.edu.ua
}

Львівський національний університет ветеринарної медицини та біотехнологій імені С.3. Гжицького, вул. Пекарська, 50, м. Львів, 79010, Украӥна

Встановлені етіологічні чинники аліментарної остеодистрофії у корів в ТзОВ імені Данила Галицького Яворівського району Львівської області. Проведено клінічне дослідження корів за аліментарної остеодистрофії. Встановлено зниження продуктивності, алотріофагію, напружену ходу, кульгавість, потовщення та болючість суглобів, розм'якшення хвостових хребиів, у важких випадках - залежуванням тварин. Вгодованість більшості тварин була нижче середньої, спостерігалася гіпотонія і атонія передшлунків, температура тіла була в межах норми. У 50\% корів відзначали блідість слизових оболонок, у 10 корів - тахіпное $(47,0 \pm 0,45$ дих.рух.хв.) і тахікардію $(110,0 \pm 3,65$ уд./хв). В 10\% корів грудна клітка була підтягнена, а хребетний стовбур - викривлений до верху. У 5 корів відмічали хитання зубів. Аналізуючи раціон годівлі корів встановлено нестачу фосфору (10-15 г), кобальту (4-5 мг), иинку (27-110 мг), йоду (5-6 мг), иукру (120-180 г), купруму (2426 мг), вміст каротину (20-30 мг), надлишок кальиію (14-28 г), феруму (1400-2200 мг), мангану (210-360 мг). В крові дослідних корів встановили зниження рівня гемоглобіну (на 10,6\%), кількості еритроцитів (18,8\%), порівняно з тваринами контрольної групи. Лейкоформула у хворих корів характеризувалась зниженням кількості базофілів (9\%), еозинофілів (47,6\%), паличкоядерних (82,3\%) і сегметоядерних (4\%) нейтрофілів, моночитів (13,3\%) $і$ збільшенням кількості лімфоцитів (11\%).У сироватиі крові дослідних встановили зниження вмісту загального білка (7,2\%), загального кальцію (26,3\%), каротину $(22,8 \%)$ та кобальту $(58,8 \%)$.

Ключові слова: велика рогата худоба, аліментарна остеодистрофія, клінічний статус корів, кров, еритроцити, лейкоиитарна формула, загальний білок, загальний кальцій, неорганічний фосфор, каротин, ферум, манган, купрум, кобальт, йод.

\section{Этиология и клинико-биохимические показатели крови при алиментарной остеодистрофии коров}

\author{
Л.Г. Сливинская, С.К. Демидюк, А.Р. Щербатый, В.Л. Федоровыч, І.О. Тындык \\ therapy@lvet.edu.ua
}

\begin{abstract}
Львовский национальный университет ветеринарной медицины и биотехнологий имени С.3. Гжицкого, ул. Пекарская, 50, г. Львов, 79010, Украина
\end{abstract}

\begin{abstract}
Установлены этиологические факторы алиментарной остеодистрофии у коров в ООО имени Даниила Галиикого Яворивского района Львовской области. Проведено клиническое исследование коров за алиментарной остеодистрофии. Установлено снижение производительности, алотриофагию, напряженную ходу, хромоту, утолщение и болезненность суставов, размягчение хвостовых позвонков, в тяжелых случаях - залеживание животных. Упитанность большинства животных была ниже средней, наблюдалась гипотония и атония преджелудков, температура тела была в пределах нормы. $B$ $50 \%$ коров отмечали бледность слизистых оболочек, в 10 коров - тахипноэ $(47,0 \pm 0,45$ дих.дв. /мин.) и тахикардию (110,0 \pm 3,65 уд./мин). В 10\% коров грудная клетка была подтянуты, а позвоночный ствол-искривленный вверх. В 5 коров отмечали колебания зубов. Анализируя раиион кормления коров установлена недостача фосфора (10-15 2), кобальта (4-5 мг), ичинка (27-110 мг), йода (5-6 м2), сахара (120-180 г), меди (24-26 мг), содержание каротина (20-30 мг), избыток кальиия
\end{abstract}

\section{Citation:}

Slivinska, L., Demydjuk, S., Shcherbatyy, A., Fedorovich, V., Tyndyk, I. (2017). Etiology and clinical biochemical parameters of blood for nutritional osteodystrophy cows. Scientific Messenger LNUVMBT named after S.Z. Gzhytskyj, 19(73), 79-83. 
(14-28 2), железа (1400-2200 мг), марганца (210-360 мг). В крови опытных коров установили снижение уровня гемоглобина (на 10,6\%), количества эритроцитов (18,8\%) по сравнению с животньми контрольной группь. Лейкоформула у больньх коров характеризовалась снижением количества базофилов (9\%), эозинофилов (47,6\%), палочкоядерньх (82,3\%) и сегметоядерних (4\%) нейтрофилов, моноцитов (13,3\%) и увеличением количества лимфоцитов (11\%). В сыворотке крови опьтнных установили снижение содержания общего белка (7,2\%), общего кальция (26,3\%), каротина (22,8\%) и кобальта (58,8\%).

Ключевые слова: крупный рогатый скот, алиментарная остеодистрофия, клинический статус коров, кровь, эритроцииты, лейкограмма, общий белок, общий кальций, неорганический фосфор, каротин, железо, марганец, медь, кобальт, йод.

\title{
Etiology and clinical biochemical parameters of blood for nutritional osteodystrophy cows
}

\author{
L. Slivinska, S. Demydjuk, A. Shcherbatyy, V. Fedorovich, I. Tyndyk \\ therapy@1vet.edu.ua \\ Lviv National University of Veterinary Medicine and Biotechnologies named after S.Z. Gzhytskyi, \\ Pekarska Str., 50, Lviv, 79010, Ukraine
}

\begin{abstract}
Established etiological factors of nutritional osteodystrophy cows LLC Danylo Galician Yavoriv district, Lviv region. A clinical study on nutritional osteodystrophy cows. A decrease in productivity, alotriophagy, strained course, lameness, thickening and tenderness of the joints, softening of the caudal vertebrae, in severe cases - the formation of animals have been established. The fatness of most animals was below average, hypotension and atony of the predniegens were observed, body temperature was within the norm. In 50\% of cows pallor of the mucous membranes was noted, in $10 \mathrm{cows}$ - tachypnea (47.0 \pm 0.45$)$ and tachycardia (110.0 \pm 3.65). In 10\% of the cows, the thorax was pulled up, and the vertebral trunk-curved upwards. In 5 cows, fluctuations of the teeth were noted. Analyzing the diet of feeding cows, a shortage of phosphorus (10-15 g), cobalt (4-5 mg), zinc (27-110 mg), iodine (5$6 \mathrm{mg})$, sugar (120-180 g), copper (24-26 mg), carotene content (20-30 mg), excess calcium (14-28 g), iron (1400-2200 mg), manganese (210-360 mg). In the blood of experimental cows, the level of hemoglobin was reduced (by 10.6\%), the number of erythrocytes (18.8\%) in comparison with the animals in the control group. Leukoformula in cows was characterized by a decrease in the number of basophils (9\%), eosinophils (47.6\%), stabnoid (82.3\%) and segmented (4\%) neutrophils, monocytes (13.3\%) and an increase in lymphocyte count $(11 \%)$. In the blood serum of the experienced, a decrease in the total protein content (7.2\%), total calcium (26.3\%), carotene (22.8\%) and cobalt (58.8\%) was established.
\end{abstract}

Key words: cattle, alimentary osteodystrophy, clinical status of cows, blood, red cells, leukocyte formula, total protein, total calcium, inorganic phosphorus, carotene, iron, manganese, copper, cobalt, iodine.

\section{Вступ}

Сучасна технологія тваринництва підвищує ризик виникнення у тварин метаболічних розладів. Серед незаразних, одними з найбільш поширених є хвороби обміну речовин, зокрема спричинені порушенням макроелементів (Levchenko et al., 2004; Heinrikhs, 2011; Levchenko et al., 2015). Основними чинниками остеодистрофії у тварин $\epsilon$ порушення годівлі та гіподинамія, а провідними ланками іiі патогенезу - дисбаланс між формуванням і резорбцією кістки. Роль аліментарного фактора полягає у незбалансованій та недостатній годівлі тварин. Особливе значення має недостатнє надходження з кормами кальцію і фосфору та порушення співвідношення цих елементів у раціонах. Окрім вмісту кальцію та фосфору в раціоні, необхідно також враховувати вміст мікроелементів. В етіології остеодистрофії певну роль відіграє нестача кобальту, цинку, купруму, мангану, які беруть активну участь у формуванні кісткової тканини та механізмах регенерації в разі ушкодження кісток (Slivinska, 2000).

Особливістю більшості хвороб спричинених порушенням обміну речовин $\epsilon$ те, що вони мають субклінічний перебіг. Він характеризується тим, що симптоми хвороби або зовсім не проявляються, або мають не типовий характер. Проведення гематологічних та біохімічних досліджень дозволяють встановити різні функціональні зміни в організмі тварин і розробити профілактику захворювання. При цьому слід враховувати господарські та біохімічні особливості даного регіону, умови в яких утримуються тварини, їхню продуктивність та метаболічний профіль крові організму. Останній може слугувати базовою характеристикою стану здоров'я тварин і продуктивності (Levchenko et al., 2000; Fedorovych, 2011; Levchenko et al., 2012).

Проблема вивчення аліментарної остеодистрофії тварин $є$ актуальною, оскільки окремі ланки патогенезу залишаються маловивченими, зокрема зв'язок мікроелементозів (Underwood and Suttle, 2001; Pavlov et al., 2005; Demydiuk et al., 2015).

Метою наших досліджень було встановити етіологічні чинники у виникненні аліментарної остеодистрофії, вивчити клінічний стан та інформативність вмісту макро- і мікроелементів у крові корів.

\section{Матеріал і методи досліджень}

Дослідження проводили на базі ТзОВ імені Данила Галицького Яворівського району Львівської області та кафедрі внутрішніх хвороб тварин та клінічної діагностики. Об'єктом досліджень були 130 корів української чорно-рябої породи на останньому місяці тільності та перших місяцях лактації. Лабораторні показники крові досліджували в 30 корів.

Захворювання спостерігались в осінньо-зимововесняний період (жовтень-грудень та лютий-квітень). Етіологію аліментарної остеодистрофії вивчали шляхом проведення діагностичного етапу диспансеризації, який включав аналіз використання тварин, умов годівлі, утримання, стан обміну речовин, синдрома- 
тику стада. На цьому етапі досліджували кров для встановлення рівня білкового, мінерального та вітамінного обміну. Клінічне дослідження тварин проводили за методикою Л.Г. Слівінської (2000) на основі аналізу господарських показників. Для вивчення клінічного статусу стада проводили клінічний огляд i вибіркове повне клінічне дослідження тварин контрольної групи. При огляді звертали увагу на загальний стан, вгодованість, стан кістково-зв'язкового апарату. Окрім цього, визначали стан шерстного покриву, шкіри, видимих слизових оболонок, лімфатичних вузлів, щитоподібної залози, зубів, копитного рогу, частоту серцевих скорочень, характер серцевих тонів, частоту та глибину дихання, ритм, частоту і силу скорочень рубця, температуру тіла (за наявності ознак хвороби).

У крові визначали кількість лейкоцитів, еритроцитів, вміст гемоглобіну - на гематологічному аналізаторі Mythic 18. У сироватці крові - вміст загального білка, неорганічного фосфору та загального кальцію на біохімічному аналізаторі Mindray BS - 120; мікроелементи - методом полум'яної фотометрії за Г.О. Бабенком; каротин - методом фотоелектроколориметрії; резервну лужність - за Раєвським; йод в сироватці крові і кормах - методом фотоелектроколориметрії за Г.С. Степановим. Хімічний склад кормів визначали за загальноприйнятою схемою зооаналізу. Вміст цукрів і водорозчинних фракцій протеїну - за методикою, описаною А.В. Петербурзьким; каротин модифікованим методом П.Х. Попандопуло.

Математичну обробку результатів досліджень опрацьовували статистично за допомогою пакета програм Statistica 6.0. Розбіжності між середніми значеннями вважали статистично вірогідними за $\mathrm{P}<0,05$ (ANOVA).

\section{Результати та їх обговорення}

Годівля корів у зимовий період проводилася за кормовими раціонами, складеними з урахуванням живої маси 400 кг, надою - 15-20 кг, жирності молока 3,2$3,4 \%$ і наявності кормів: сіно - 3-4 кг, солома - 34 кг, силос - 15-16 кг, кормовий буряк - 10-15 кг, комбікорм - 4-5 кг, при наявності, макуха - 1 кг.

Проведенням аналізу раціону годівлі корів встановлено нестачу: кормових одиниць (1-2 кг), фосфору (10-15 г), кобальту (4-5 мг), цинку (27-110 мг), йоду (5-6 мг), цукру (120-180 г), купруму (24-26 мг), каротину (20-30 мг). Відмічали надлишок кальцію (1428 г), феруму (1400-2200 мг), мангану (210-360 мг), перетравного протеїну (40-64 г).

У господарстві в зимово-стійловий період аліментарна остеодистрофія клінічно проявлялася зниженням продуктивності, спотвореним апетитом, напруженою ходою, кульгавістю, потовщенням та болючістю суглобів, розм'якшенням хвостових хребців, у важких випадках - залежуванням тварин. Вгодованість більшості тварин була нижче середньої, спостерігалася гіпотонія і атонія передшлунків, температура тіла була в межах норми. У 50\% корів відзначали блідість слизових оболонок, у 10 корів - тахіпное $(47,0 \pm 0,45$ дих.рух./хв.) i тахікардію $(110,0 \pm$
3,65 уд./хв). В 10\% корів грудна клітка була підтягнена, а хребетний стовбур - викривлений до верху. У 5 корів відмічали хитання зубів. При вимушеному забої 4 (13,3\%) тварин та розробці туш відмічали деформацію, в окремих місця потовщення i бугристість, розм'якшення кісток, наявність на ребрах овальних потовщень, а також потовщень суглобів, особливо у місцях прикріплення сухожилків.

Одним із важливих показників функціонального стану органів кровотворення та обміну мікроелементів в організмі $є$ еритроцитопоез. Для визначення стану еритроцитопоезу та біохімічного статусу корів, сформовано 2 групи (дослідну і контрольну) по 15 тварин у кожній.

Вміст гемоглобіну в крові дослідної групи знаходився в межах 95,0-106,2 г/л $(103,0 \pm 0,40)$ і був вірогідно (Р < 0,001) менший на $10,6 \%$, ніж у контрольної (табл.1).

За результатами дослідження показників гемопоезу встановлено, що кількість еритроцитів у крові дослідних корів в середньому становила 4,8 $\pm 0,22 \mathrm{~T} /$, що на $18,8 \%(\mathrm{P}<0,05)$ менше порівняно з контролем. Олігоцитемія та олігохромемія є наслідком недостатнього забезпечення тварин поживними та біологічно активними речовинами, необхідними для еритроцитопоезу (Underwood and Suttle, 2001; Demydiuk et al., 2015).

За багатьох порушень функціонального стану i структури окремих органів настає реакція з боку кровотворних органів, яка супроводжується кількісними і якісними змінами крові, зокрема лейкоцитів.

Гематологічні показники крові корів

Таблиияя 1 $(\mathbf{M} \pm \mathbf{m}, \mathbf{n}=\mathbf{3 0})$

\begin{tabular}{|c|c|c|}
\hline \multirow{2}{*}{ Показники } & \multicolumn{2}{|c|}{ Групи тварин } \\
\cline { 2 - 3 } & Контрольна & Дослідна \\
\hline Гемоглобін, г/л & $114,0 \pm 0,22$ & $103,0 \pm 0,40^{* * *}$ \\
\hline Еритроцити, Т/л & $5,7 \pm 0,30$ & $4,8 \pm 0,22^{*}$ \\
\hline Лейкоцити, Г/л & $6,8 \pm 0,54$ & $5,7 \pm 0,41$ \\
\hline Базофіли & $1,2 \pm 0,18$ & $1,1 \pm 0,14$ \\
\hline Еозинофіли & $6,2 \pm 1,30$ & $4,2 \pm 1,10$ \\
\hline Паличкоядерні & $6,2 \pm 2,01$ & $3,4 \pm 1,24$ \\
\hline Сегметоядерні & $21,0 \pm 3,20$ & $20,2 \pm 4,10$ \\
\hline Лімфоцити & $58,6 \pm 5,01$ & $65,1 \pm 5,24$ \\
\hline Моноцити & $6,8 \pm 1,94$ & $6,0 \pm 2,12$ \\
\hline
\end{tabular}

Примітки: $\mathrm{P}<0,05^{*} ; 0,001 * * *$ - порівняно зконтрольною

Середня кількість їх у корів дослідної групи знаходилась нижче нижньої фізіологічній межі $(6,0-$ 12,0 Г/л); $(5,7 \pm 0,41$ Г/л).

Лейкоформула у дослідних корів характеризувалась зниженням кількості базофілів (9\%), еозинофілів (47,6\%), паличкоядерних (82,3\%) і сегметоядерних (4\%) нейтрофілів, моноцитів (13,3\%) і збільшенням кількості лімфоцитів (11\%) порівняно 3 тваринами контрольної групи.Отже, показники кількості еритроцитів, лейкоцитів, рівня гемоглобіну вказують на розвиток у корів аліментарної анемії, причиною якої $\epsilon$, очевидно, нестача кобальту, купруму та мангану в раціоні.

За дослідження біохімічних показників в організмі корів за аліментарної остеодистрофії нами встановле- 
но ряд закономірностей, які, з одного боку, характеризують особливості їх фізіологічного стану, а 3 іншого - вказують на значні зміни в метаболізмі (табл. 2).

Нами встановлено, що рівень загального білка в сироватці крові дослідних корів знаходився у межах 64,0-73,5 г/л і становив у середньому 69,0 \pm 0,10 г/л (табл. 2), що на 7,2\% (Р<0,001) менше порівняно 3 контролем.

Причиною гіпопротеїнемії, очевидно, може бути порушення синтезу окремих його фракцій, недостатне надходження в організм з кормом.

Вміст каротину в сироватці крові дослідних тварин був меншим за фізіологічні показники $(8,4$ 18,6 мкмоль/л) (Levchenko et al., 2000) і в середньому становив 3,5 $\pm 0,37$ мкмоль/л, що на 22,8\% менше порівняно з контрольною групою корів.

Вміст загального кальцію у корів дослідної групи вірогідно (Р < 0,01) зменшувався на 26,3\% порівняно 3 контролем, що пов’язано, на нашу думку, з порушенням кальціє-фосфорного співвідношення у раціоні і крові корів. У корів контрольної групи рівень кальцію знаходився на нижній межі фізіологічних коливань (2,4-3,2 ммоль/л).

Уміст іншого макроелемента - неорганічного фосфору знаходився в межах від 1,15 до 1,56 ммоль/л $(1,4 \pm 0,02)-$ у корів дослідної групи, за норми $1,5-$ 2,2 ммоль/л.

Табличя 2

Біохімічні показники крові корів $(\mathbf{M} \pm \mathbf{m}, \mathbf{n}=\mathbf{3 0})$

\begin{tabular}{|l|c|c|}
\hline \multirow{2}{*}{\multicolumn{1}{|c|}{ Показники }} & \multicolumn{2}{|c|}{ Гмрупт в сироватці або крові } \\
\cline { 2 - 3 } & Контрольна & Дослідна \\
\hline Загальний білок, г/л & $74,0 \pm 0,12$ & $69,0 \pm 0,10^{* * *}$ \\
\hline Каротин, мкмоль/л & $4,3 \pm 0,56$ & $3,5 \pm 0,37$ \\
\hline $\begin{array}{l}\text { Резервна лужність, } \\
\text { об\%СО } 2\end{array}$ & $47,2 \pm 1,20$ & $40,0 \pm 1,10^{* * *}$ \\
\hline $\begin{array}{l}\text { Загальний кальцій, } \\
\text { ммоль/л }\end{array}$ & $2,4 \pm 0,10$ & $1,9 \pm 0,12^{* *}$ \\
\hline $\begin{array}{l}\text { Неорганічний фосфор, } \\
\text { ммоль/л }\end{array}$ & $1,6 \pm 0,03$ & $1,4 \pm 0,02^{* * *}$ \\
\hline Ферум, мкмоль/л & $20,4 \pm 0,20$ & $24,1 \pm 0,26^{* * *}$ \\
\hline Манган, мкмоль/л & $2,3 \pm 0,04$ & $1,9 \pm 0,32$ \\
\hline Купрум, мкмоль/л & $20,7 \pm 2,52$ & $13,6 \pm 2,12^{*}$ \\
\hline Кобальт, мкмоль/л & $0,27 \pm 0,01$ & $0,17 \pm 0,01 * * *$ \\
\hline Цинк, мкмоль/л & $19,1 \pm 1,18$ & $20,2 \pm 1,14$ \\
\hline
\end{tabular}

Примітки: $\mathrm{P}<0,05^{*} ; 0,001 * *$ - порівняно з контрольною

Гіпофосфатемія (менше 1,5 ммоль/л) встановлена у 100\% корів. Встановлений низький рівень Р вказує на розвиток у корів гіпофосфатемії, яка $€$ показником остеодистрофії.

Враховуючи специфічні особливості областей Західного регіону України, нами визначався в крові корів уміст $\mathrm{Fe}, \mathrm{Mn}, \mathrm{Co}, \mathrm{Cu}, \mathrm{Zn}$, J оскільки їм належить найбільше значення в еритроцитопоезі.

Ферум необхідний, як компонент для синтезу гемоглобіну, є складовою частиною ферментів антиоксидантного захисту, бере участь у тканинному окисненні, окисно-відновних процесах в організмі, стимулює обмін речовин, імунобіологічні реакції, кровотворення, ріст і розвиток тварин (Levchenko et al.,
2004). Як показали результати наших досліджень, кількість феруму в сироватці крові у корів усіх груп знаходилась у межах фізіологічних коливань (1530 мкмоль/л). У дослідних корів - в середньому $24,1 \pm$ $0,26 \quad(18,1 \% ; \quad \mathrm{P}<0,001), \quad$ контрольних $-20,4 \pm$ 0,20 мкмоль/л відповідно.

Манган активує кістковий ізофермент лужної фосфатази та інші ферменти, які беруть участь у біосинтезі елементів органічного матриксу і його мінералізації (Pavlov et al., 2005). Вміст мангану у корів дослідної і контрольної груп був більшим за фізіологічні коливання і в середньому становив $1,9 \pm 0,32$ і $2,3 \pm$ 0,04 мкмоль/л відповідно.

У формуванні кісткової тканини та іiї функціонуванні важливого значення надають біогенним мікроелементам. За дефіциту купруму у кістковій тканині збільшується вміст розчинного колагену і затримується перетворення його у зрілий колаген, тому розвивається дифузний остеопороз (Pavlov et al., 2005). Необхідно відмітити, що його кількість у крові корів дослідної групи була найменшою і в середньому становила $13,6 \pm 2,12$ мкмоль/л (12,4-13,7), що на 52,2\% вірогідно (Р < 0,05) менше порівняно 3 контролем. Гіпокупремія встановлена у 50\% досліджених корів.

Кобальт стимулює засвоєння кальцію і фосфору, посилюючи протеолітичну активність шлункового та панкреатичного соків, активує кістковий і кишковий ізоферменти лужної фосфатази, кислу фосфатазу, стимулює включення фосфору в кісткову тканину, синтез органічної i мінеральної частини кістки (Levchenko et al., 2004). Вміст кобальту в крові корів обох груп був нижчим за фізіологічну норму і в середньому становив у дослідній групі $0,17 \pm$ 0,01 мкмоль/л $(58,8 \% ; \mathrm{P}<0,001)$, контрольній $-0,27 \pm$ 0,01 мкмоль/л.

Цинк бере участь у процесах кальцифікації, активуючи лужну фосфатазу. За його дефіциту активність ферменту у хондроцитах епіфізарного хряща знижується, що спричиняє порушення остеогенезу (Levchenko and Kondrakhin, 2002; Levchenko et al., 2004; Enjalbert et al., 2006; Provatorov et al., 2009). Вміст цинку у всіх корів знаходився в межах фізіологічних коливань (15-23 мкмоль/л).

У разі тривалого недостатнього надходження мінеральних речовин з кормом або низького рівня їх засвоєння кісткова тканина збіднюється на кальцій, фосфор, магній та інші елементи, настає їх демінералізація (остеомаляція), яка проявляється передусім у кістках, що не мають опорного значення. Процеси кісткоутворення та кісткооновлення порушуються (Pavlov et al., 2005).

Отже, у біогеохімічній зоні Львівської області дефіцит мікроелементів в організмі корів настає внаслідок недостатньої їх кількості у грунтах, воді та кормах, а також внаслідок порушення співвідношення між ними. Нестача кобальту, купруму, йоду та надлишок феруму, мангану, кальцію спричиняє зменшення не лише мінерального метаболізму, а й порушення еритроцитопоезу, білоксинтезувальної функції печінки, обміну вітамінів та спричиняє розвиток остеодистрофії. 


\section{Висновки}

1. Основною причиною аліментарної остеодистрофії корів у даному господарстві $є$ недостатнє надходження з кормом фосфору в поєднанні з дефіцитом у раціоні кобальту, цинку, йоду, цукру, каротину i купруму за надлишку перетравного протеїну, кальцію, феруму та мангану. 2. Клініко-лабораторними дослідженнями було виявлено порушення обміну речовин у корів, яке проявлялося розвитком аліментарної остеодистрофії.

\section{Бібліографічні посилання}

Levchenko, V.I., Kondrakhin, I.P., Vlizlo, V.V. (2012). Vnutrishni khvoroby tvaryn: pidruchnyk. Bila Tserkva (in Ukrainian).

Heinrikhs, A. (2011). Hodivlia ta utrymannia koriv u sukhostiinyi period. Zhurnal «Moloko i ferma». 1(04), 56-61 (in Ukrainian).

Levchenko, V.I., Kondrakhin, I.P., Bohatko, L.M. (2000). Zahalna terapiia i profilaktyka vnutrishnikh khvorob tvaryn: Praktykum. Bila Tserkva (in Ukrainian).

Pavlov, M.S., Maslii, M.I., Pysarenko, V.F. (2005). Osoblyvosti diahnostyky i profilaktyky khvorob, sprychynenykh porushenniam obminu rechovyn. Vet. medytsyna: Mizhvid. temat. nauk, zb. 85(2), 885-887 (in Ukrainian).

Levchenko, V.I., Vlizlo, V.V., Kondrakhin, I.P. (2004). Klinichna diahnostyka vnutrishnikh khvorob tvaryn. Bila Tserkva (in Ukrainian).

Levchenko,V.I., Vlizlo,V.V., Kondrakhin, I.P. (2015). Vnutrishni khvoroby tvaryn: pidruchnyk. Bila Tserkva, 2 (in Ukrainian).
Slivinska, L.H. (2000). Dyspanseryzatsiia koriv (metodychni rekomendatsii). Lviv, 40 (in Ukrainian).

Demydiuk, S.K., Shcherbatyi, A.R., Lukashchuk, B.O. (2015). Syndromatyka stada koriv v NNVTs «Komarnivskyi» Horodotskoho raionu Lvivskoi oblasti. Nauk. visnyk Lviv. nats. un-tu vet. medytsyny ta biotekhnolohii imeni S.Z. Gzhytskoho. 17, 1(61), 1, 47-51 (in Ukrainian).

Fedorovych, V.L. (2011). Profilaktyka osteodystrofii koriv $\mathrm{v}$ umovakh bioheokhimichnoi zakhidnoi zony. Nauk. visnyk Lviv. nats. un-tu vet. medytsyny ta biotekhnolohii imeni S.Z. Gzhytskoho. seriia «Veterynarni nauky». 13, 4(50), 1, 472-476 (in Ukrainian).

Underwood, E.J., Suttle, N.F. (2001). The Mineral Nutrition of Livestock. CABI Publishing.

Levchenko, V.I., Kondrakhin, I.P. (2002). Veterynarna klinichna biokhimiia. Bila Tserkva (in Ukrainian).

Provatorov, H.V., Ladyka, V.I., Bondarchuk, L.V. (2009). Normy hodivli, ratsiony i pozhyvnist kormiv dlia riznykh vydiv silskohospodarskykh tvaryn: dovidnyk. Sumy: Universytetska knyha (in Ukrainian).

Enjalbert, F., Pebreton, L., Salat, O. (2006). Effects of copper, zinc and selenium status on performance and health in commercial dairy and beef herds: retrospective study. Journal of Animal Physiology and Animal Nutrition. 90, 459-466.

Banzaite, V., Klimiene, I., Spakauskas, V., Matusevicius, A. (2005). Interaction between the levels of hormones and minerals in sera of healthy and sick cows. Pol. J. Vet. S. 8(4), 269-274.

Стаття надійшла до редакиії 28.02.2017 